\title{
Virtual Fairy Tale Based on Wulangreh as a Learning Media in Javanese Lesson
}

\author{
S Agustin ${ }^{*}$, Sunardi², D Rochsantiningsih ${ }^{2}$, Gunarhadi $^{2}$, R Perdana $^{1}$ \\ \{septiana.agustin@gmail.com,sunardi.ipuns@gmail.com, \\ dewi_roch@hotmail.com,gunarhadi@fkip.uns.ac.id \} \\ ${ }^{1}$ Doctoral Program of Educational Science, Universitas Sebelas Maret, Surakarta, Indonesia \\ ${ }^{2}$ Teacher Training and Education Faculty of Universitas Sebelas Maret, Surakarta, Indonesia
}

\begin{abstract}
This study aims to investigate the available virtual fairy tale based on wulangreh in primary school as one of the learning media in primary school. Data collection techniques in this study are observation and interviews in 30 primary school libraries, both public school and private school. The results showed that 30 school libraries already have fiction books, non-fiction books, teaching aids, and video teaching materials for subjects of mathematics, science, social studies, Indonesian and cultural art, while the virtual fairy tales based on wulangreh have not been found. Thus, it can conclude that the virtual tales based on wulangreh are not found. The recommendation of further research is to provide the fairy tale based on wulangreh as a learning media
\end{abstract}

Keywords: $\quad$ virtual, fairy tale, learning, media

\section{Introduction}

Active, effective, interesting, and fun learning can be created by teachers through alternative strategies in the delivery of teaching materials (Malone, Schunn, \& Schuchardt, 2018; Martin, Martinez, et al, 2018). One strategy are to utilize media, methods, and visual aids in learning activities (Darmansyah, 2011; Khanifatul, 2014; Lee \& Jones, 2018) tailored to the level of student understanding (Whisken, 2017). By using various media, props and method development in learning, the learning activities will not feel saturating. Learners will be more enthusiastic, passionate, discipline, and motivated by their creativity (Dominguez, et al 2013; Thomas, 2013, Zepeda, et al, 2015). With the passion and motivation of learners, the learning activity will be increased quality of the development of learners (Egert, Fukkink, \& Eckhardt, 2018; Vondel, et al, 2017).

The most important thing in improving the qualities of education is the willingness of teachers to be creative and responsible for the success of his work (Chatib, 2011). Teachers who teach with high creativity can motivate, inspire, and encourage students to have high expectations of the material they are learning about (Morris, 2006). Sometimes, the creative thinking ability possessed by the students is hampered by 
the lack of resources, both the teacher as the facilitator, and the curriculum as the main means and source of learning activities (Craft, Jeffrey, \& Leibling, 2001; Aldiq $\&$ Arseven, 2017). Therefore, many organized training or seminars aimed to improving the qualities of teachers in teaching (Kraft, Blazar, \& Hogan, 2018).

The developments of the 21 st century cannot separate from the use of virtual technology based. The virtual sense is a simulation of the real thing. With regard to virtual, current education is also enforced systems that implement about virtual learning (Nesson, Nesson, 2008). Virtual technology has a lot of potential and knowledge to apply in learning activities (Chiou, 1995). One of the cyberspace technology favored by children is the applications of The Second Life (Woods, Wentz, \& Baker, 2009). Inside the application, children can choose characters that have a variety of characters and personality. Then the child can also interact with others and the environment, through the program The Second Life. Virtual classroom or so-called online environment, used by some technology-based educational institutions (Anyanwu, 2003). The online environment makes students comfortable and gives a positive impression. Students can easily interact socially, enjoy easy access to learn, and enhance their creativity and experience (Branley \& Covey, 2018; Guardadao \& Palladino, 2017; Loftin, Dede, \& Salzman, 1995; Brelsford, 1993).

The tale is one of the best methods used to cultivate literacy to illiterate societies (Vitali, 2016) and instill noble values of children. Through fairy tales also, children learn to develop imagination, express themselves, cultivate a sense of humor, extending the imagination, sharpen emotional experience and pick up the implicit message behind the fairy tales (Agus, 2009). Fairy tales that are displaying digitally, need more detailed and complete components. In addition, learning to use digital fairy tales also requires good designs and representation of space and time (Calvert, Bizzocchi, \& Wei, 2010). The utilization of digital storytelling (Tunjera, et al, 2015) is also applied for several universities especially in the primary school teacher program. Not only teachers, but prospective teachers are also given material about the method of storytelling to children. This case the application of learning media digital storytelling. When telling story processing, teachers can invite students to communicative by involving students to take part in playing the characters in the fairy tale (Palacio, 2010).

Every teacher does not necessarily have good storytelling skills, this can see from the instructional design used by teachers, who never use storytelling methods. Therefore, it needs a learning media that can help the teachers to able to deliver the fairy tales to the students. Based on the results of interviews for elementary school teachers can conclude that the form of fairy tales that fit with current technological developments is virtual video. The material of fairy tale should adjust to the technological development, but not leave the culture of the region. Therefore, fairy tale material suitable for children based on the study of regional cultural literacy 
is wulangreh. Based on the above description, this article will describe the availabilities of a virtual fairy tale based on wulangreh in Javanese lesson.

wulangreh is one of the Javanese philosophy that contains the values of moral. It packed in macapat song. This explanation contains elements of character values, ethical norms, morality, and character building. One of the uniqueness of macapat song is every song has its own character. Each song has character and values of different characters. The values of the characters of the song are useful as the principle of human life in this world.

\section{Methods}

The population of this study was elementary school at ambarawa. Sampling was taken from 30 elementary school principals. The sample was chosen from the principal at ambarawa because they are responsible for all programs, activities, and implementation of education in schools. Including school facilities, services, and availability of reference books in the library. The data used in this study are secondary data in the form of data collection of books and learning media in the elementary school library. Especially, about the availability of wulangreh virtual fairy tale in elementary school library This secondary data is reinforced by the results of interviews with the principal at ambarawa. The method used in this study is descriptive qualitative. The description of the results of the survey and interview will be described in descriptive form. Instruments used: survey sheets and questionnaires for interviews. Data collection techniques are obtained by analyzing survey results, and interviews.

\section{Results and Discussion}

Based on the observations, it was found that libraries in 30 primary schools have fiction books, non-fiction books, visual aids, and learning videos for science materials, Social, mathematics, Indonesia language, and cultural art. The virtual tales based on wulangreh have not been found. This is reinforced by interviews for principal at core school 1 and 2. The result states that the core school has fiction, nonfiction, props, and teaching materials for language, math, science, and sports lessons. Virtual fairy tale will become the important part that should be learnt in the elementary school in Javanese class. However, virtual fairy tale for children in the elementary school is not found.

Based on the observations, it was found that libraries in 30 primary schools have fiction books, non-fiction books, visual aids, and learning videos for science 
materials, social, mathematics, Indonesia language, and cultural art. The virtual tales based on Wulangreh have not been found. This is reinforced by interviews, that is:

Interview with principal at core school 1 Ambarawa district.

Researchers : Does your school have a fiction book?

Headmaster: Yes, we have fiction books.

Researcher : Does your school have non-fiction books?

Headmaster: Yes, we have a collection of fiction books.

Researcher : Does your school have props?

Headmaster: Yes, we have props for learning Science and Language.

Researcher : Does your school have a teaching material video?

Headmaster: Yes, we have teaching materials for science, social, language, math, and cultural arts.

Interview with the principal at the core school 2 Ambarawa district.

Researchers : Do you think the learning method is appealing to children?

Principal : Method based on technological progress.

Researchers: What do you think is the right method for child development?

Principal : Method based on character values.

Researchers : Can virtual fairytale learning be applied to children?

Headmaster: Yes, I think according to technological developments of interest to children.

Researchers: Will virtual fairytale based on Wulangreh as media learning support child development?

Headmaster: Yes, because Wulangreh includes values that can be useful for character development in children.

Based on the interview for principal at core school 1, it can conclude that virtual tale has not been found in primary school. Then on the results of interviews for principal at core school 2, it can concluded that virtual fairytale based on wulangreh can apply to the primary school learning. It can see from the opinions of the principal that conveyed that the virtual fairy tale based on wulangreh in according with technological developments and includes character values.

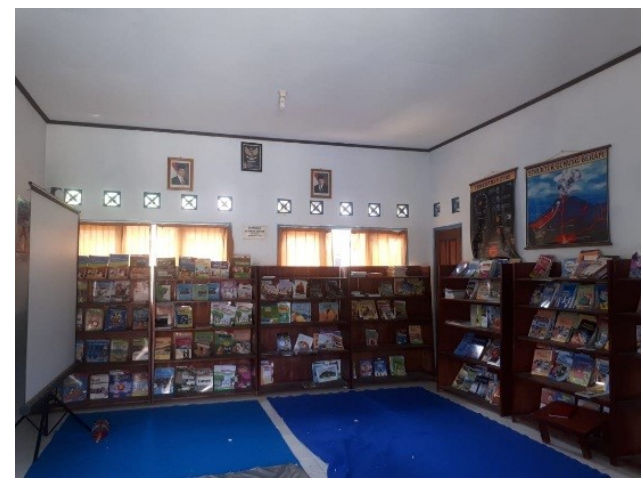

Figure 1. The Condition of Library 
Basically, every school has a library. The contents of the library are a variety of tools and teaching materials. Almost all teaching materials are always used by teachers and students in turn. Teaching materials used by teachers so far is still the type of books and props. Other teaching materials are video. A tool that can use by teachers when giving lessons with different nuances. The learning videos were used for Math, Language, Science, Social, Citizen, and Handicraft lessons. Video content was divided into two, first is a guide for teachers while the second is a guide to students. Video that contain guides to teachers consist of introduction, object, procedure, practice questions, assessments, and evaluations. Then, the second video contain lessons for children. Teaching materials works for the developments of their knowledge. Videos for children also contain the element of entertainment. It means that the children do not feel boring when learn by video learning.

Video learning is given by the teacher according to the subject. The video on virtual fairy tales intended for children. Videos about virtual tales have not been found in school libraries. The frames and contents of the virtual tale video are different from the lesson videos. The virtual fairy tale videos framed by a short drama of about 3 minutes, while the contents of the virtual fairytale video are the macapat song. Children who watch virtual fairy tales will easily catch the message contained in the video content. In addition, children can also sing along with the song macapat sung by the characters of the drama. Thus, children will get many benefits of virtual fairy tales. They can sing with cool, happy, and enjoy. They can also learn the attitudes shown through short dramas. Thus, it can conclud that virtual tale videos are very useful for children.

The development of fables that are packaged in IT packages is very interesting for children. This is caused by educational games that provide challenges for children. Besides being able to play exciting educational games, children's insights also develop through questions about stories about the local area or environment (Masmuzidin, M, Jiang J, Wan.T, 2012).

Technology development systems that utilize computer animation can support children's learning progress (Johnston, et al, 2017). Various computer animations are made applicatively with the aim of attracting children's attention. So that children can be motivated in learning. Johnston's research supports research on virtual fairy tales in terms of utilizing computer animation to create creative learning models for children. Making virtual fairy-tale videos uses several applications through computer technology, namely: applications to adjust lighting, sound sharpness, cutting scenes, moving highlights, writing song lyrics, and merging all parts to be put together into one whole video unit. 


\section{Conclusions}

This study resulted in a conclusion that the virtual fairy tales for children based on wulangreh have not available in elementary school libraries. This can see based on observations and interviews in 30 primary school libraries. Based on observations and interviews conducted from teachers, it can concluded that 30 primary school libraries have fiction books, non-fiction books, visual aids, and video teaching materials for subjects of mathematics, science, social studies, Indonesian language and cultural arts, while the virtual fairy tales based on wulangreh was not found. The observation data on the virtual fairy tale based on wulangreh search reinforce by the results of interviews of 30 principals who stated that the virtual fairy tale for students based on wulangreh had not available.

Based on the literature study, explained that virtual fairy tales become one of the learning media worthy to develop especially for elementary school students. The benefits of fairy tales for students, among others: open literacy insights, improve imagination, add creativity, and as inspiration. The virtual tale based on wulangreh used as one of the primary school learning media, because according to the level of child development, interesting to learn, in line with the developments of technology, build the character, and not leave the concept of local cultural literacy. Therefore, the recommendation for further research is providing the fairy tale based on wulangreh as a learning media

\section{References}

[1] Agus, DS (2009), Tips for telling stories, Yogyakarta: Kanisius.

[2] Aldiq, E., \& Arseven, A. (2017). The Contribution of Learning Outcomes for Listening to Creative Thinking Skills. Journal of Education and Learning; 6(3).

[3] Anyanwu, C. (2003). Myth and Realities of New Media Technology Virtual Education Premise. Sage Journal: Television and New Media. 4(4), 389-409.

[4] Branley, D. \& Covey, J. (2018). Risky behavior via social media: The role of reasoned and social reactive pathways. Computers in Human Behavior. 78, 183-191.

[5] Brelsford, J. (1993). Physics Education in a Virtual Environment. Sage Journal: Proceedings of the Human Factors and Ergonomics Society Annual Meeting. 37(18), 1286-1290.

[6] Calvert, T., Bizzocchi, J., Wei, H. (2010). Time and Space in Digital Game Storytelling. International Journal of Computer Games Technology. 23, Article ID 897217

[7] Chatib, Munif, 2011. Gurunya Manusia. Cetakan 1, Bandung: Kaifa Learning

[8] Chiou, G.F. (1995). Learning Rationales and Virtual Reality Technology in Education. Journal of Educational Technology Systems. 23(4), 327-336.

[9] Craft, Jeffrey, \& Leibling. (2001). Creativity in Education. New York: Continuum.

[10] Darmansyah. 2011. Strategi Pembelajaran Menyenangkan dengan Humor. Jakarta: Earth Script.

[11] Domínguez, et al. (2013). Gamifying learning experiences: Practical implications and outcomes. Computers and Education 63, 380-392.

[12] Egert, F., Fukkink, R., \& Eckhardt, A. (2018). Impact of In-Service Professional Development Programs for Early Childhood Teachers on Quality Ratings and Child Outcomes: A MetaAnalysis. Review of Educational Research.

[13] Guardadao, M., Palladino, V. (2017). Extending the heritage language classroom: experiences of digital technology use in two community schools in Alberta, Canada. Language, Culture and Curriculum. P. 1-18. 
[14] Johnston, et al. (2017). Exploring Pedagogical Foundations of Existing Virtual Reality Educational Applications: A Content Analysis Study. Journal of Educational Technology Systems. 0(0), 1-26.

[15] Khanifatul. 2014. Pembelajaran Inovatif. Cetakan II, Jogjakarta: Ar-Ruzz Media.

[16] Kraft, M., Blazar, D., \& Hogan, D. (2018). The Effect of Teacher Coaching on Instruction and Achievement: A Meta-Analysis of the Causal Evidence. Review of Educational Research.

[17] Lee, T. \& Jones, M. (2018). Elementary Teachers' Selection and Use of Visual Model. Journal of Science Education and Technology. 27(1), 1-29.

[18] Loftin, R., Dede, C., Salzman, M. (1995). Usability and Learning in Educational Virtual Realities. Sage Journal. Proceedings of the Human Factors and Ergonomics Society Annual Meeting. 39(9), 486-490.

[19] Malone, K., Schunn, C., \& Schuchardt, A., (2018). Improving Conceptual Understanding and Representation Skills Through Excel-Based Modeling Journal of Science Education and Technology. 27(1), 30-44.

[20] Martin, P., Martinez., et al. (2018) A study of 16 years old student learning strategies from a

[21] Neuropsychological perspective: An intervention proposal. Trends in Neuroscience and Education. 11, 1-8.

[22] Masmuzidin, M, Jiang J, Wan.T, (2012). Learning moral values through virtual technology: the development. Procedia - Social and Behavioral Sciences, 31, 315-322.

[23] Morris, W. (2006). Creativity Its Place in Education. Future Edge Ltd. New Zealand: New Plymouth.

[24] Nesson, C., Nesson, R. (2008). The Case for Education in Virtual Worlds. Sage Journal. Space and Culture. 11(3), 273-284.

[25] Palacio, C.G. (2010). Strategies to Help ESL Students Improve their Communicative Competence and Class Participation: A Study in a Middle School. HOW. 17(1).

[26] Thomas, M. (2013). Educational neuroscience in the near and far future: Predictions from the analogy with the history of medicine. Trends in Neuroscience and Education. 2(1), 23-26

[27] Tunjera, et,. al. (2015). Digital storytelling as a tool for teaching: Perceptions of pre-service teachers. The Journal for Transdisciplinary Research in Southern Africa. 11(1).

[28] Vitali, F. (2016). Teaching with Stories as the Content and Context for Learning. Global Education Review. 3(1), 27-44.

[29] Vondel, et al., (2017). Ask, don't tell; A complex dynamic systems approach to improving science education by focusing on the co-construction of scientific understanding. Teaching and Teacher Education. 63, 243-253.

[30] Whisken, A. (2017). Action Research and Informed Learning for Transformative Professional Development About Information Literacy. Media and Information Literacy in Higher Education. Educating the Educators. 135-150. Chandos Publishing

[31] Woods, M., Wentz, R., Baker, S. (2009). Using Virtual Worlds in Education: Second Life as an Educational Tool. Teaching of Psychology. 36(1), 59-64.

[32] Zepeda, et al. (2015). Direct instruction of metacognition benefits adolescent science learning, transfer, and motivation: An in vivo study. Journal of Educational Psychology, 107(4), 954-970. 